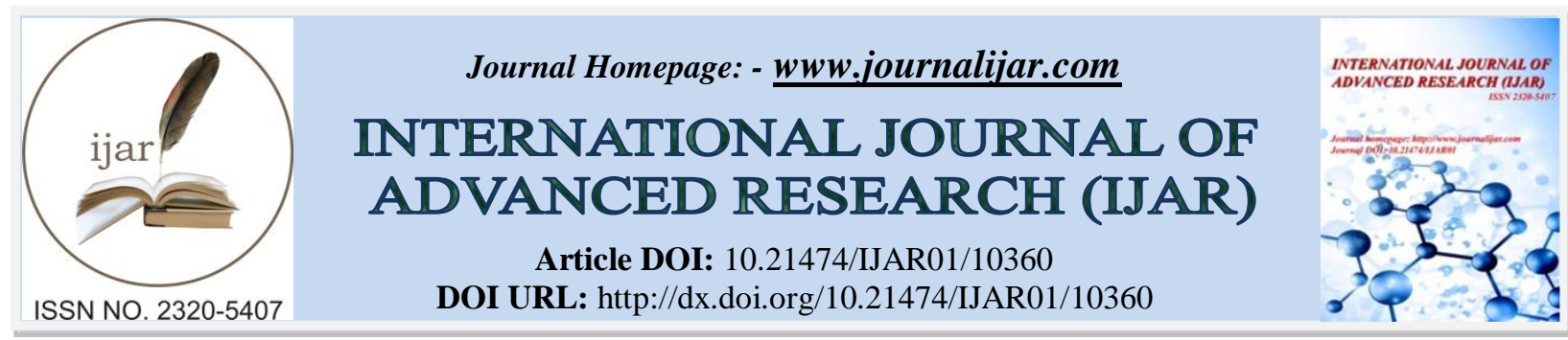

RESEARCH ARTICLE

\title{
THE SEMANTIC, CONNOTATIVE AND PRAGMATIC PECULIARITIES OF ANTHROPOCENTRIC PROVERBIAL CONSTRUCTIONS IN THE ENGLISH, UZBEK AND KARAKALPAK LANGUAGES
}

Jalgasov Nurjan Maratovich

English Teacher, Doctoral Student of Nukus State Pedagogical Institute Named After Ajiniyaz.

\section{Manuscript Info}

(..........................

Manuscript History

Received: 30 November 2019

Final Accepted: 31 December 2019

Published: January 2020

Key words:-

Proverbial Construction, Semantic,

Connotative, Pragmatic,

Anthropocentric, Evaluation, Situation

\begin{abstract}
The present manuscript is devoted to investigation of semantic, connotative and pragmatic peculiarities of proverbial constructions which characterize a human. The author pays attention to semantic meaning of such proverbs, connotative signs of evaluating people. Besides, pragmatic means of proverbial formations are analyzed in the manuscript. Theoretical part of the manuscript is proved by examples of proverbial constructions.
\end{abstract}

Copy Right, IJAR, 2020,. All rights reserved.

\section{Introduction:-}

\section{Materials and Methods:-}

The material of the present research - proverbial constructions or proverbs of the English, Uzbek and Karakalpak languages which characterize a human, that's why they are called anthropocentric proverbs. We have used descriptive method for describing the problem of investigation, method of critical analysis of the literature on the present theme of investigation, componential analysis for analyzing components of proverbial constructions as well as semantic-structural approach.

\section{Results and Discussion:-}

A.V. Kunin considers proverbial constructions as aphorismic expressions with rhythmically organized form and advising meaning [A.V. Kunin, 2005, p. 432]. Proverbs are the pearls of people's wisdom, spiritual richness and cultural heritage of people, experiences during many centuries [P.U. Bakirov, 2018, p. 98].

The majority of proverbs of any language is connected with description of people's characteristics and reflect attitude to them due to any concrete situation or event. From generation to generation proverbs transfer valuable information about human's nature and his role in society.

Really, with the help of proverbs in human's cognition various images are created as well as people's feeling and sufferings are reflected in the surrounding of objects and people of the world. Proverbial constructions are created by people but they are registered in language system in special dictionaries. Proverbs are able to demonstrate language bearers' culture and national spirit of the language.

A proverbial construction always has a model of a sentence with complete idea.

Corresponding Author:- Jalgasov Nurjan Maratovich

Address:- English Teacher, Doctoral Student of Nukus State Pedagogical Institute Named After Ajiniyaz. 


\section{For example: \\ English proverb:}

Don't ride the high horse (because it is dangerous);

Uzbek proverb: Ўзингга эхтиёт бўл, кўшнингни ўғри тутма (Be careful about your things and don't complain that your neighbor is a thief);

Karakalpak proverb: Сырын билмеген аттын сыртынан айланба (Don't go to the place which is unfamiliar to you).

The proverbial constructions of three languages: English, Uzbek and Karakalpak, can be classified according to classification worked out by N.Z. Nasrullaeva (2018). This classification includes the following parametres: 1) appearance; 2) age; 3) character and personal qualities; 4) marital status; 5) social status and professional activity; 6) behavior and lifestyle; 7) intellect [N.Z. Nasrullaeva, 2018, p. 51-52].

Proverbial constructions can be expressed by the structure of simple or compound sentences. It should be noted, that the majority of proverbs are simple and laconic sentences which have deep meaning. Long proverbs are difficult to remember in memory, that's why they fall out of everyday use. As for short proverbs, they are very popular and are widely used in speech and texts.

As great Russian scientist-phraseologist A.V. Kunin noted, proverbs are expression of people's wisdom and are characterized by a high level of abstraction which make them useful in different life-related situations [A.V. Kunin, 2005, p. 434].

Proverbs reflect various spheres of human activity. In some theoretical issues proverbs called proverbial constructions (as in the present manuscript) or paremiological units. All of them are equal in meaning. They convey people's knowledge and life experience from generation to generation for many, many centuries.

English proverb: What soberness conceals, drunkenness reveals (when a person has drunk alcohol, he/she may say something which he/she would never tell being sober);

Uzbek proverbs: Хушёрнинг дилида - мастнинг тилида (the same meaning as above mentioned English proverb: when a person has drunk alcohol, he/she may say something which he/she would never tell being sober);

Karakalpak proverb: Аққа қара жоқ, қараға шара жоқ (a white can’t be black and black can’t be white).

In proverbial constructions laconic and short speech is praised:

English proverb (created by W. Shakespeare): Brevity is the soul of wit (it's better to be short in speaking);

Uzbek proverb (created by Avicenna): Соғлиқ тиласанг - кўп ема, хурмат тиласанг - кўп гапирма (if you want to be healthy - don't eat much, if you want to be respected - don't talk much);

Karakalpak proverb: Адамнын ардақлы адам болмағы сейлеген сезинен, журген жолынан белгили (a bird is estimated by flying, a person - by speaking).

\section{Proverbs laugh at fools:}

English proverb: A fool always rushes to the fore (a fool always hurries forward);

Uzbek proverb: Ахмоқнинг киссаси тешик (a fool has holed pockets and can’t gather money);

Karakalpak proverb: Бир жаманнын кесапатынан аққан дерья қурыйды (a fool will tie in such way that ten wisemen can't untie).

Especially rich people and their domination among common people are criticized in proverbs: 
English proverb: Thief passes for a gentleman when stealing has made him rich (people begins to respect a rich person though he might be not decent before);

English proverb: One law for the rich, and another for the poor (the position of rich and common people is not equal)

Many proverbs convey people's wisdom:

English proverb: Never put off till tomorrow what you can do today (it's better to do everything in time and not to postpone);

English proverb: Time is a good healer (time passes and everything becomes better);

Uzbek proverb: От айланиб, айланиб, қозиғини топар (a horse runs to and fro but comes back to its own place).

Proverbial constructions teach a person to follow a healthy lifestyle, to work, help each other and study:

English proverb: Virtue is her (its) own reward (a person who does good and kind acts doesn't need in award in back);

English proverb: It's never late to learn (a person can study and get knowledge at any age);

Uzbek proverb: Хечдан кўра кеч (better late than never).

Proverbs call people to have friendly relations:

English proverb: A friend in need is a friend indeed (a real friend will never leave in difficult situation);

Uzbek proverb: Дўст ёмон кунда билинар (A friend can be experienced in bad days);

Karakalpak proverb: Дос жылатып айтады, душпан кулдирип айтады (a friend will scold if you do mistake, but an enemy will smile).

It is known that proverbial constructions can be expressed by declarative, interrogative and imperative sentences.

One of the main features of proverbial constructions id absence of polysemy. It means that one proverb can have one definite meaning. So, it can be used in an exact contextual surrounding. If a proverb is incorrectly used due to this or that situation in the process of speech act, it can cause misunderstanding between communicants.

Many linguists investigated the origin of proverbs and they came to conclusion that people, people's mind is the only author of proverbs. Proverbs are created by people and they are used by people in order to characterize people. Each situation has its own proverb. For example, if a daughter looks like her mother the following English proverb can be used: Like mother, like daughter. The same meaning has the Uzbek proverb Онасини кўриб қизини ол.

In situation when a wise person makes mistake the following English proverb is used: A good marksman may miss. In the Uzbek language we have a proverb with the same meaning: Хар тўкисда бир айб. In Karakalpak language we have a proverb Айда да дақ бар (even the moon has spots).

\section{Conclusion:-}

We can conclude that proverbial constructions are the mostly used language means both in oral communication and written texts. Short and laconic form, refined structure and deep meaning make them popular in everyday speech and literary books, newspaper texts and mass media. One proverb can depict the whole situation and transfer a person's attitude to any object, event or another person. According to structure proverbial constructions can be expressed by simple or compound sentences. According to way of expression they can be expressed by declarative, interrogative and imperative sentences. Proverbial constructions have semantic, connotative and pragmatic peculiarities. They have deep meaning used in order to transfer different connotative marks and evaluation of people 
in the frame concrete situation. The proverbial constructions of three languages: English, Uzbek and Karakalpak have been investigated. The Uzbek and Karakalpak languages have much in common, because these languages belong to one language family, are spoken within one republic - Republic of Uzbekistan and have many similar customs, traditions due to identical history and religion. As for English, it has many differences with Uzbek and Karakalpak, because of different history, geography, religion, culture, mentality, way of thinking, life style, etc. So, the present manuscript has reflected similarities and differences between two kindred languages: Uzbek and Karakalpak and unrelated to them the English language.

\section{Literature:-}

1. Bakirov P.U. Concept and proverbs. // Philology and intercultural communication. Materials of Republic conference. - Tashkent, 2018. - P. 98-101.

2. Kunin A.V. The course of modern English phraseology. - Dubna: Fenix+, 2005. - 488 p.

3. Nasrullaeva N.Z. The formation of gender concepts in the English and Uzbek phraseological world vision. Abstract of doctoral dissertation. - Tashkent, 2018. - $70 \mathrm{p}$. 